Sains Malaysiana 50(5)(2021): 1309-1320

http://doi.org/10.17576/jsm-2021-5005-11

\title{
Biosynthesis of Gold Nanoparticles (AuNPs) by Diopatra claparedii Grube, 1878 (Polychaeta: Onuphidae) and Its Antibacterial Activity
}

(Biosintesis Nanozarah Emas (AuNPs) daripada Diopatra claparedii Grube, 1878 (Polychaeta: Onuphidae) dan

Aktiviti Antibakterianya)

\author{
Piong Chong Huai, Noor Aniza Harun*, Angeline Ung Ee Pei, Mohammad Asyraf Adhwa Masimen, \\ WAN IRYANI WAN ISMAIL, IZWANDY IDRIS
}

\begin{abstract}
Gold nanoparticles (AuNPs) have gained attention as it possesses outstanding physicochemical properties, and utilised in variety of applications especially in biomedical and pharmaceutical. Majorly, AuNPs are produced by conventional methods (chemical and physical). However, these methods bring several drawbacks such as toxic, hazardous, low yield and non-environmental friendly. Hence, biosynthesis of AuNPs that compliance with 'greener' approach becomes vitals. In this study, marine tube worm of Diopatra claparedii (polychaetes) was employed as reducing agent in the biosynthesis of AuNPs. The biosynthesised of AuNPs by D. claparedii extract was successfully prepared under ambient temperature and normal atmospheric conditions. The formation of AuNPs was confirmed by the appearance of surface Plasmon resonance (SPR) bands around 540 to $560 \mathrm{~nm}$ characterized by UV-Vis spectroscopy. Scanning electron microscopy (SEM) showed that the AuNPs are mostly in agglomerated spherical like shapes with size ranging from 100 to $400 \mathrm{~nm}$. Meanwhile, transmission electron microscopy (TEM) showed that the particles are in the size range from 25 to $60 \mathrm{~nm}$, also mainly form in spherical like shape. The particle size of AuNPs in a range of 50-100 nm was showed by dynamic light scattering (DLS). Fourier-transform infrared (FTIR) spectrum of D. claparedii extract indicated the existence of several functional groups. Biosynthesised AuNPs also successfully gave inhibition on bacterial growth (Staphyloccus aureus, S. epidermidis, Escheratia coli, Salmonella typhi) through antibacterial assessment.
\end{abstract}

Keywords: Antibacterial; biosynthesis; Diopatra claparedii; gold nanoparticles; polychaete

ABSTRAK

Nanozarah emas (AuNP) telah mendapat perhatian kerana memiliki sifat fizikokimia yang luar biasa dan digunakan dalam berbagai aplikasi terutama dalam bidang bioperubatan dan farmaseutik. Sebahagian besarnya, AuNP dihasilkan dengan kaedah konvensional (kimia dan fizikal). Walau bagaimanapun, kaedah ini mempunyai beberapa kelemahan seperti toksik, berbahaya, memakan masa, kadar penghasilan yang rendah dan tidak mesra alam. Oleh itu, biosintesis AuNPs menggunakan pendekatan sintesis 'hijau' menjadi penting. Dalam kajian ini, cacing marin bertiub Diopatra claparedii telah digunakan sebagai agen penurun dalam biosintesis AuNPs. Biosintesis AuNPs oleh ekstrak D. claparedii telah berjaya disintesis dalam suhu normal dan dalam keadaan atmosfera biasa. Pembentukan AuNPs telah disahkan oleh puncak permukaan Plasmon resonans (SPR) sekitar 540 sehingga 560 nm yang dicirikan oleh spektroskopi UV-Vis. Mikroskopi elektron pengimbasan (SEM) menunjukkan bahawa AuNPs dihasilkan dalam bentuk sfera yang beraglomerat dalam saiz antara 100 hingga $400 \mathrm{~nm}$. Sementara itu, mikroskopi elektron transmisi (TEM) menunjukkan bahawa AuNPs dihasilkan dalam saiz antara 25 hingga $60 \mathrm{~nm}$, juga dalam bentuk sfera secara majoriti. Saiz zarah AuNPs dalam lingkungan 50-100 nm telah didedahkan oleh serakan cahaya dinamik (DLS). Spektrum inframerah transformasi Fourier (FTIR) D. claparedii menunjukkan kewujudan beberapa kumpulan berfungsi. Biosintesis AuNPs juga berjaya memberi keputusan terhadap perencatan bakteria (S. aureus, S. epidermidis, E. coli, S. typhi) melalui penilaian antibakteria.

Kata kunci: Antibakteria; biosintesis; Diopatra claparedii; nanozarah emas; poliket 


\section{INTRODUCTION}

Gold nanoparticles (AuNPs) refer to particles of gold in size ranging from 1 to $100 \mathrm{~nm}$. AuNPs have received great amount of attentions due to their outstanding electronic (Saxena \& Goswami 2012), optical (Carrillo-Cazares et al. 2017; Ogarev et al. 2018), mechanical (Kim et al. 2019), chemical and physical properties (Gatoo et al. 2014; Yeh et al. 2012). AuNPs have unique properties of employing larger surface area to volume ratio, different sizes and shapes due to which they are exhibit enormous potential in various fields of biotechnology and biomedicine, such as protein and DNA detection (Yang et al. 2014), cancer diagnostic and therapy (Rengan et al. 2015), drug delivery (Daraee et al. 2014), bio imaging (Yang et al. 2019), catalysis, biosensor, antimicrobial agent, optoelectronics, cosmetics and space science (Soumya et al. 2017). Additionally, nano-sized gold possesses interesting plasmonic properties in comparison to their bulk due to localized surface Plasmon resonance (LSPR) effect, which occurs when incident light interacts with electrons on the surface of electro-conductive nanoparticles (Amendola et al. 2017; Karimi et al. 2018). On account of outstanding properties and various applications, AuNPs are considered to be real jewels due to their significant growth especially in biology and/or life science.

The production of AuNPs mainly divided by two major techniques, either via chemical reduction or physical reduction. Generally, chemical reduction involves two main steps, which are, gold (III) ion reduced by reducing agent such as borohydrides, ascorbates, and hydroxylamine, then followed stabilization of AuNPs by stabilising agent for instance surfactants and polymers (Herizchi et al. 2014). Meanwhile, physical reduction involves size reduction of gold particles by different methods, such as, laser ablation (Correard et al. 2014), lithography (Huang et al. 2012), radiolysis (Freitas de Freitas et al. 2018) and physical vapour deposition (Lee et al. 2018). Even though these two conventional methods are well-established and widely employed for industrial purposes, however, the production of AuNPs by using these methods have lots of drawbacks, for example, used toxic and hazardous chemicals, low yield of desired product, high energy-consumption, high cost, and timeconsuming (Menon et al. 2017).

As the nano-revolution unfolds, there is a growing need to develop environmentally benign nanoparticles synthesis process that does not involve toxic chemicals in the synthesis protocols to address growing concerns on the overall toxicity of nanoparticles especially for medical and technological applications. The green biosynthesis of nanoparticles can be achieved via the selection of an environmentally acceptable solvent with eco-friendly reducing and stabilizing agents. Living organism for instance plants, fungi, bacteria, and algae have enormous potential for the production of nanoparticles (Ahmad et al. 2016; Menon et al. 2017; Ravindran et al. 2013; Singh et al. 2016). The synthesis of nanoparticles by using biological systems is advantageous over chemical and physical approaches as it is cost effective, high biocompatibility, easy to synthesis and environmentally friendly which does not require high pressure, energy, temperature, or toxic chemicals (Zhang et al. 2016).

Among various types of natural biogenic reducing agents that widely utilized to produce AuNPs, marine organism, in particular polychaetes is one of the ecofriendly reducing agents that has been known to have potentiality to synthesis nanoparticles (Hussain et al. 2018; Pei et al. 2020; Singh et al. 2014). Polychaete is an invertebrate marine organism, characterized by a worm-like segmented body. Generally, polychaetes have relatively smaller size compared to other invertebrate marine organisms. Nonetheless, some of them still able to grow up to 6 metres and lives mostly free living (errantia) or in tube (sedantaria); a small number of species live as obligate swimmers (Glasby et al. 2000). Diopatra claparedii is one of the sedantaria polychaetes (tubeworm) in Malaysia. Occasionally collected as fishing bait, $D$. claparedii can only be found in tidal flat adjacent to mangrove zonation along the west coast of Malay Peninsula (Paxton 2002).

Review of the literature showed that the synthesis of nanoparticles using marine invertebrate of polychaete has been very rare, where, only three studies have reported the successful of biosynthesis silver nanoparticles (AgNPs) (Hussain et al. 2018; Singh et al. 2014) and AuNPs (Pei et al. 2020) using polychaetes as reducing agents. Thus, it is reasonable to explore and discover more about the potentiality of different polychaete species as reducing agent for the synthesis of AuNPs. Hence, this study is exploring the potential of $D$. claparedii as reducing agent in the synthesis of AuNPs as a safer alternative technique towards the current nanoparticle synthesis approach.

\section{MATERIALS AND METHODS}

POLYCHAETE SAMPLING

Specimens of $D$. claparedii together with its tube were collected from the lower tidal flat zone during low tide 
at Morib, Selangor. The sediment was also collected as it is required to create artificial aquaria for the polychaete storage, prior to the experiment. In the laboratory, the specimens were placed in the artificial aquaria together with its sediment at ambient temperature and salinity 30 ppt.

\section{POLYCHAETE EXTRACT PREPARATION}

Fresh polychaetes samples were cut and finely pulverised using mortar and pestle, with each were separated according to specific weight of $5,10,15$, and $20 \mathrm{~g}$, respectively. Sterile double distilled water $(100 \mathrm{~mL})$ was added into each $250 \mathrm{~mL}$ beaker containing polychaetes samples with different mass. Each sample solution was filtered through filter paper (Ø $125 \mathrm{~mm}$ ) to separate the solution from the tissue pieces (Singh et al. 2014).

\section{BIOSYNTHESIS OF AUNPS}

The biosynthesis of AuNPs were prepared according to a modification of a literature method described in Hussain et al. (2018). A triplicate of filtered polychaetes extract solution $(5 \mathrm{~mL})$ from each mass was mixed with gold (III) chloride trihydrate $\left(\mathrm{HAuCl}_{4} \cdot 3 \mathrm{H}_{2} \mathrm{O}\right)(1 \mathrm{mM})$ solution $(20 \mathrm{~mL})$ in a $100 \mathrm{~mL}$ Erlenmeyer flask (wrapped with aluminium foil) at room temperature. The flasks were agitated at $150 \mathrm{rpm}$ in the dark condition at $30{ }^{\circ} \mathrm{C}$. The solution mixtures were incubated in incubator (Innova ${ }^{\circledR}$ 44, New Brunswick) and the colour changes were observed by $0 \mathrm{~h}, 2 \mathrm{~h}, 24 \mathrm{~h}, 1$ week, 1 month, 2 months, and 3 months. Citrate-stabilised AuNPs were synthesised using chemical reduction method (Turkevich et al. 1953) were taken as positive control and polychaete extract solution and $\mathrm{HAuCl}_{4} \cdot 3 \mathrm{H}_{2} \mathrm{O}$ solutions acted as the negative control.

\section{CHARACTERIZATIONS OF BIOSYNTHESIS GOLD NANOPARTICLES}

\section{UV-VIS SPECTROSCOPY ANALYSIS}

UV-Vis spectroscopy was used to determine the formation of biosynthesised AuNPs by evaluation the SPR spectra. The SPR spectra was obtained at the wavelength ranging from 450 to $800 \mathrm{~nm}$ using UV-Vis spectrophotometer (UV1800 , Shimadzu) and the graph was plotted by automated software UV Probe 2.42 .

SCANNING ELECTRON MICROSCOPY (SEM) The morphology of biosynthesised AuNPs was observed under SEM (JSM-6360LA, JEOL) at 15 - $20 \mathrm{kV}$ accelerating voltage. All samples were prepared by mounting process where few drops of samples were deposited onto dry poly-L-lysine and the sample was coated with gold via sputter coating (Auto Fine CoaterJEOL).

\section{TRANSMISSION ELECTRON MICROSCOPY (TEM)}

TEM was employed to determine more precise average particle size and detailed morphology of biosynthesised AuNPs. The samples were observed by TEM (1200 EX II, JEOL) under accelerating voltage of $200 \mathrm{kV}$. For sample preparation, one drop of biosynthesised AuNPs was dropped on a copper mesh grid and left to dry.

\section{DYNAMIC LIGHT SCATTERING (DLS)}

Average hydrodynamic diameter $\left(\mathrm{D}_{\mathrm{h}}\right)$ and polydispersity index (PDI) of biosynthesised AuNPs were obtained using dynamic light scattering (DLS) (Zatasizer nano Zs, Malvern Instruments) at $25 \pm 0.1^{\circ} \mathrm{C}$ with scattering angle of $90{ }^{\circ} \mathrm{C}$. The sample solutions were transferred into a plastic cuvette and measurement were performed three times.

\section{FOURIER TRANSFORM INFRARED SPECTROSCOPY (FTIR)}

IR absorption spectrum of the negative control (polychaetes extract) was determined using FTIR spectrometer (Spectrum 100 Series, PerkinElmer) in order to prove AuNPs are not produced from polychaetes. But instead the nanoparticles are produced from biosynthesis activity with the polychaete extract. The powder sample was prepared using $\mathrm{KBr}$ disk ( $3 \%$ of $\mathrm{KBr}$ ) and the IR absorption spectrum was scanned between $400 \mathrm{~cm}^{-1}$ and $4000 \mathrm{~cm}^{-1}$ using Nicolet 520 FTIR Spectrophotometer.

\section{ASSESSMENT OF ANTIBACTERIAL ACTIVITY}

The antibacterial activity of AuNPs was conducted using Kirby-Bauer disc diffusion method against two Gram-positive bacteria; Staphylococcus aureus and S. epidermidis and two Gram-negative bacteria; Escherichia coli and Salmonella typhi. The bacterial cultures were grown on nutrient agar (NA) before spread uniformly on a solidified Muller Hinton Agar (MHA) plates by using cotton swabs and incubated overnight at $37{ }^{\circ} \mathrm{C}$. Sterile filter paper discs of $6 \mathrm{~mm}$ were loaded with samples (20 $\mu \mathrm{L})$. There were six samples which containing tetracycline (positive control), citrate-stabilised AuNPs (positive control), polychaetes extract (negative control), double distilled water (negative control) and biosynthesised AuNPs (DioAuNPs_15g and DioAuNPs_20g, respectively). MHA plate was then incubated overnight at $37^{\circ} \mathrm{C}$. Zone of inhibition (ZOI) diameter was measured. 


\section{RESULTS AND DISCUSSION}

PHYSICAL APPEARANCE OF AUNPS

The successful formation of AuNPs can be initially visualised by colour changes of the solution from pale yellow to red-ruby solution during the incubation period. From Figure 1, citrate-stabilised AuNPs (positive control) obtained as red-ruby solution and the colour was maintained even after three months. Meanwhile, aqueous D. claparedii extract solution and aqueous $\mathrm{HAuCl}_{4} \cdot 3 \mathrm{H}_{2} \mathrm{O}$ solution did not show any colour changes after three months proving that there is no formation of AuNPs were observed.

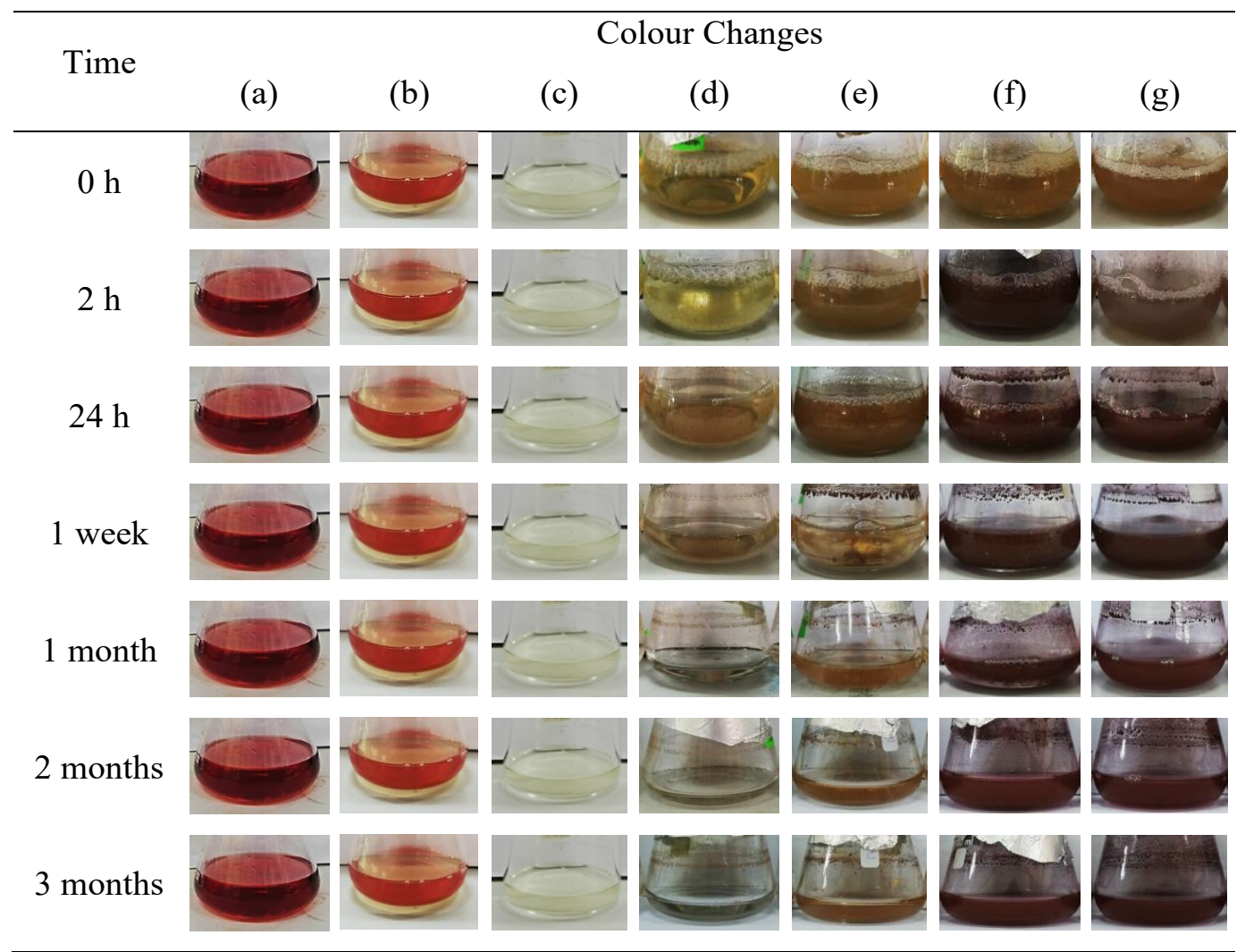

FIGURE 1. Colour changes from reducing activity of polychaetes (D. claparedii) with gold (III) chloride trihydrate precursor indicating the formation of AuNPs: (a) citrate-stabilised AuNPs (positive control), (b) aqueous D. claparedii extract solution (negative control), (c) aqueous $\mathrm{HAuCl}_{4} \cdot 3 \mathrm{H}_{2} \mathrm{O}$ solution (negative control), (d) DioAuNPs_5g, (e) DioAuNPs_10g, (f) DioAuNPs_15g, and (g) DioAuNPs_20g

AuNPs that synthesised using $5 \mathrm{~g}$ of $D$. claparedii (DioAuNPs $5 \mathrm{~g}$ ) exhibits negative result as the colour did not turn to red-ruby colour but gradually turned to colourless after three months observation (Figure 1(d)). This outcome indicates that $5 \mathrm{~g}$ of $D$. claparedii extract did not sufficient for the bio-reduction of AuNPs to be happened. In contrary, when the mass of $D$. claparedii increased to $10 \mathrm{~g}$ (DioAuNPs_10g), the colour of solution slightly changed from yellow to dark brown (Figure 1(e)). However, $10 \mathrm{~g}$ of $D$. claparedii extract is still considered insufficient to reduce gold $(\mathrm{Au})$ ions to AuNPs as the samples did not turn to red-ruby solution. 
Interestingly, AuNPs_15g and AuNPs 20g (Figure $1(\mathrm{f})-1(\mathrm{~g})$ ) which prepared using 15 and $20 \mathrm{~g}$ of $D$. claparedii extract, respectively, exhibit positive results. The yellow solution of $\left(1 \mathrm{mM}\right.$ of $\left.\mathrm{HAuCl}_{4} .3 \mathrm{H}_{2} \mathrm{O}\right)$ turned to red-ruby solution after $2 \mathrm{~h}$ of incubation. The change of colour is believed due to the change of oxidation state (reduction process) of gold ions from $\mathrm{Au}^{3+}$ to $\mathrm{Au}^{0}$ with the help of bio components in $D$. claparedii (Abdel-Raouf et al. 2017).

\section{UV-VIS SPECTROSCOPY}

The presence of SPR bands of AuNPs can be observed under UV-Vis spectrophotometer within the range of 520 to $580 \mathrm{~nm}$ (Dzimitrowicz et al. 2016). Figure 2 depicts the comparison of UV-Vis spectra for all biosynthesised AuNPs and control samples that observed from 2 and 24 $\mathrm{h}$ incubation, and then continued to observe after 1 week, 1 month, 2 months and up to 3 months.

The SPR band of citrate-stabilised AuNPs as positive control was observed at $519 \mathrm{~nm}$. In contrast, there were no SPR bands observed for both negative controls confirming that the samples do not contain AuNPs; proving that AuNPs formed was not obtained either from $D$. claparedii extract or $\mathrm{HAuCl}_{4} \cdot 3 \mathrm{H}_{2} \mathrm{O}$ solution.
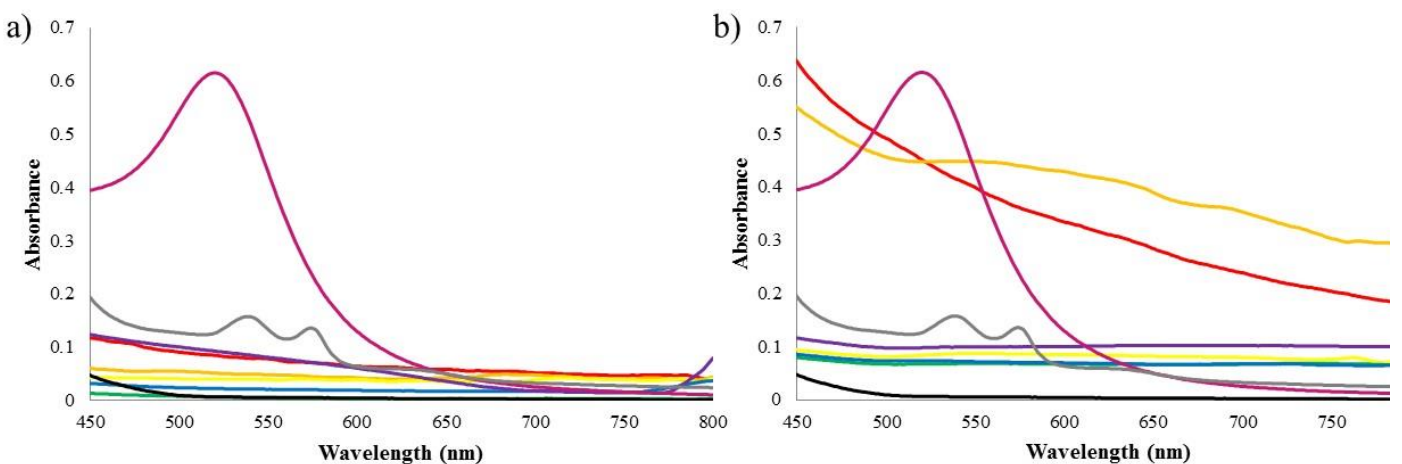

c)

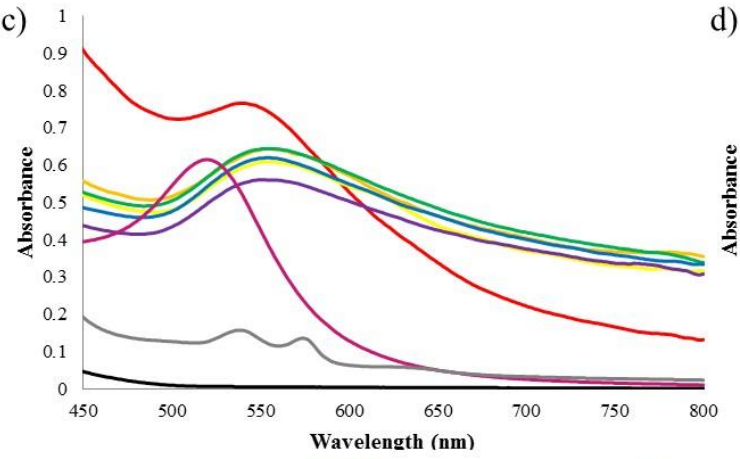

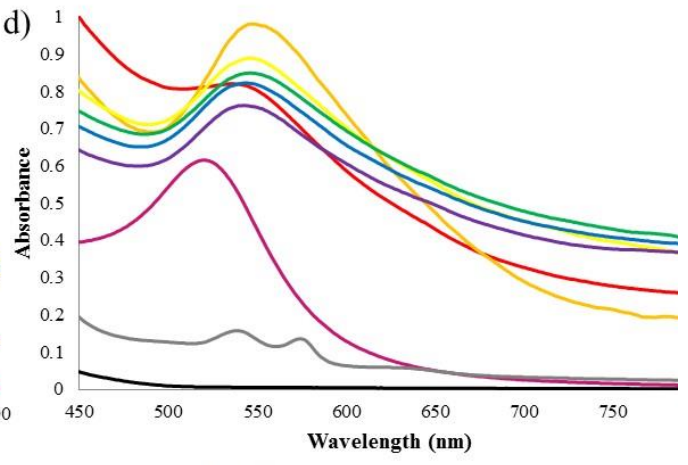

$\begin{array}{lll}-2 \text { hours } & -24 \text { hours } & 1 \text { week } \\ -1 \text { month } & -2 \text { months } & -3 \text { months } \\ - \text { Citrate-stabilised AuNPs } & - \text { D. claparedii Extract } & - \text { Gold Precursor Solution }\end{array}$

FIGURE 2. Comparison of UV-Vis spectra of positive control, negative controls and biosynthesised AuNPs prepared using different masses of Diopatra claparedii observed after 2 and $24 \mathrm{~h}$ of incubation, after 1 week, 1 month, 2 months and 3 months observations: (a)

DioAuNPs_5g, (b) DioAuNPs_10g, (c) DioAuNPs_15g, and (d) DioAuNPs_20g 
DioAuNPs $5 \mathrm{~g}$ and DioAuNPs $10 \mathrm{~g}$ which were unsuccessful to obtain AuNPs showed no evidence for SPR bands of AuNPs present in both spectra throughout three months of observation (Figure 2(a) - 2(b)). On the other hand, DioAuNPs_15g and DioAuNPs_20g showed the formation of SPR bands that observed in a range of $539-551$ and $535-547 \mathrm{~nm}$, respectively (Figure 2(c) - 2(d)). Formation of red-ruby colour solution in both samples leads to the existence of SPR bands confirming the formation of AuNPs. This finding is in agreement with the previous study reported by several groups (AbdelRaouf et al. 2017; Onitsuka et al. 2019; Yuan et al. 2017). From this characterisation, it is confirmed that 15 and $20 \mathrm{~g}$ of $D$. claparedii extracts are adequate to reduce $\mathrm{Au}$ ions to produce biosynthesised AuNPs. However, maximum wavelength of SPR band for both samples are red shifted relative to the positive control (citrate-stabilised AuNPs) on account of several properties of AuNPs formed by different methods, for instance, effects of their size, shape, and morphology (Hussain et al. 2018).
Additionally, the SPR bands of DioAuNPs_15g and DioAuNPs_20g were broader when observed up to 3 months. The changes in SPR bands might due to the aggregation of AuNPs. The larger the size of AuNPs, the more red-shifted the maximum wavelength of SPR band. Furthermore, since the absorbance of AuNPs is directly proportional to amount of AuNPs, agglomeration of AuNPs is believed to be one of the reasons for the absorbance of SPR bands decreased (Ahmad et al. 2013).

\section{SCANNING ELECTRON MICROSCOPY}

Scanning electron microscopy (SEM) characterisation was employed in this study to determine the size and morphology of biosynthesised AuNPs. Based on the SEM images in Figure 3, AuNPs obtained are mainly formed in spherical-like shape in agreement with previous reported studies (Ahmad et al. 2016; Apte et al. 2013; Latha et al. 2018). However, these particles tend to agglomerate and clump to each other. As the incubation time passes, AuNPs tend to achieve more stable state in the respect of energy level by clumping to each other (Ahmad et al. 2013).

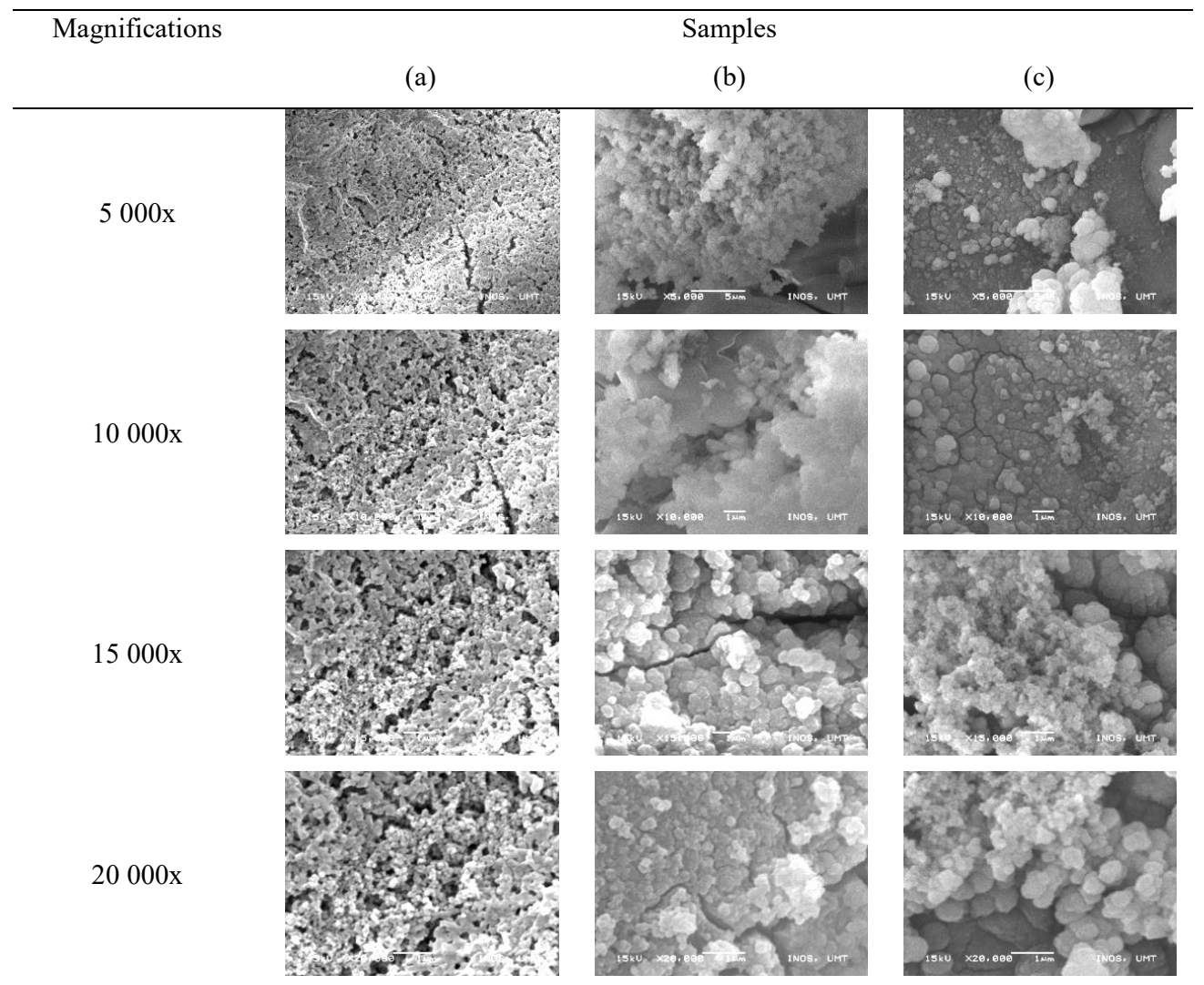

FIGURE 3. SEM images with different magnifications: (a) citrate-stabilised AuNPs, (b) DioAuNPs_15g, and (c) DioAuNPs_20g 
In addition, the sample preparation is also one of the reasons for the particles aggregation to be happened. Due to the agglomeration, the average particle size of AuNPs was larger. Citrate-stabilised AuNPs have average particle size approximately around $102 \mathrm{~nm}$. Meanwhile, DioAuNPs_15g and DioAuNPs_20g showed the average particle size of 300 and $239 \mathrm{~nm}$, respectively.
TRANSMISSION ELECTRON MICROSCOPY (TEM)

Transmission electron microscopy (TEM) was further utilised to identify the structure and average particle sizes of biosynthesised AuNPs and citrate-stabilised AuNPs as it has higher resolution in comparison to scanning electron microscope.
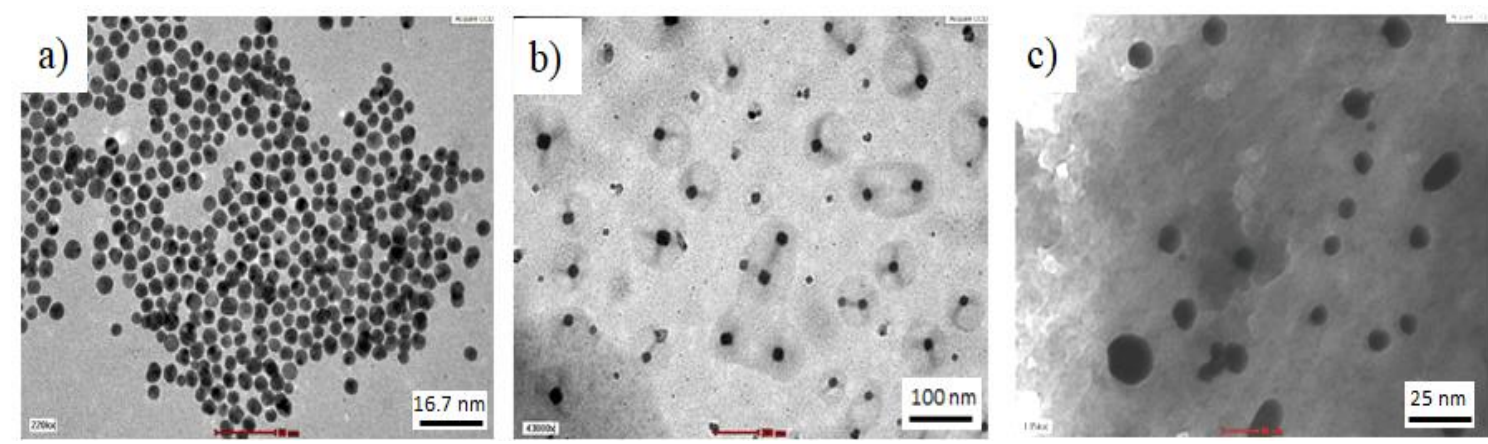

FIGURE 4. Transmission electron microscopy (TEM) images of samples: (a) Citratestabilised AuNPs (positive control) (220 000× magnification), (b) DioAuNPs $15 \mathrm{~g}$ (43 000× magnification), and (c) DioAuNPs_20g (135 000× magnification)

Based on Figure 4, citrate-stabilised AuNPs were mainly formed as monodispersed spherical-like shape particles with average particle size in a range of $8-17 \mathrm{~nm}$. DioAuNPs 15g (Figure 4(b)) and DioAuNPs 20g (Figure 4(c)) were also successfully observed under TEM and both of the sample were also employed as spherical-like shape with average particle sizes are between 40-66 and 34-60 nm, respectively. From both of biosynthesised AuNPs, the average particles sizes of DioAuNPs_15g are slightly larger than AuNPs_20g. This finding is in agreement with the observation from UV-Vis spectrophotometer, where the SPR bands of DioAuNPs $15 \mathrm{~g}$ are slightly red shifted relative to DioAuNPs_20g.

\section{DYNAMIC LIGHT SCATTERING (DLS)}

Dynamic Light Scattering (DLS) provides characterisation of particle size and particle size distribution of the samples in solution. The DLS data obtained from citrate-stabilised AuNPs, DioAuNPs_15g and DioAuNPs_20g were summarized in Table 1 and Figure 5. The hydrodynamic mean particle diameter $\left(D_{h}\right)$ of citrate-stabilised AuNPs (positive control) is $20.6 \mathrm{~nm}$, with PDI value of 0.288 . In contrary, DioAuNPs_15g and DioAuNPs_20g have larger particle size of $73.5 \mathrm{~nm}$ and $94.4 \mathrm{~nm}$, respectively, in comparison to the positive control (Figure 5). The PDI values that obtained from all biosynthesied AuNPs and citrate stabilised AuNPs were in the range of $0.248-0.295$, and this PDI values are within acceptable range of below 0.500 .

TABLE 1. Hydrodynamic mean particle diameter (Dh) and polydispersity index (PDI) of citrate-stabilised AuNPs (positive control), DioAuNPs_15g and DioAuNPs_20g determined by DLS

\begin{tabular}{lcc}
\hline \multicolumn{1}{c}{ Sample } & Hydrodynamic diameter, $\mathrm{D}_{\mathrm{h}}(\mathrm{nm})$ & Polydispersity index, PDI \\
\hline Citrate stabilised AuNPs & 20.6 & 0.288 \\
DioAuNPs_15g & 73.5 & 0.248 \\
DioAuNPs_20g & 94.4 & 0.295 \\
\hline
\end{tabular}


However, the particle size of AuNPs analysed by DLS was observed to be larger compared to the data obtained from TEM. The possible explanation for this finding may be due to the DLS measurement was determined the hydrodynamic size which includes the thickness of any coating presence on the surface of AuNPs, for instance stabilising and capping agents, resulting in larger size of the particle (Ahmad et al. 2016; Nadaf \& Kanase 2019). Moreover, the presence of interference in the aqueous solution during characterisation might also contribute to overestimation of AuNPs size (Zhang et al. 2016).

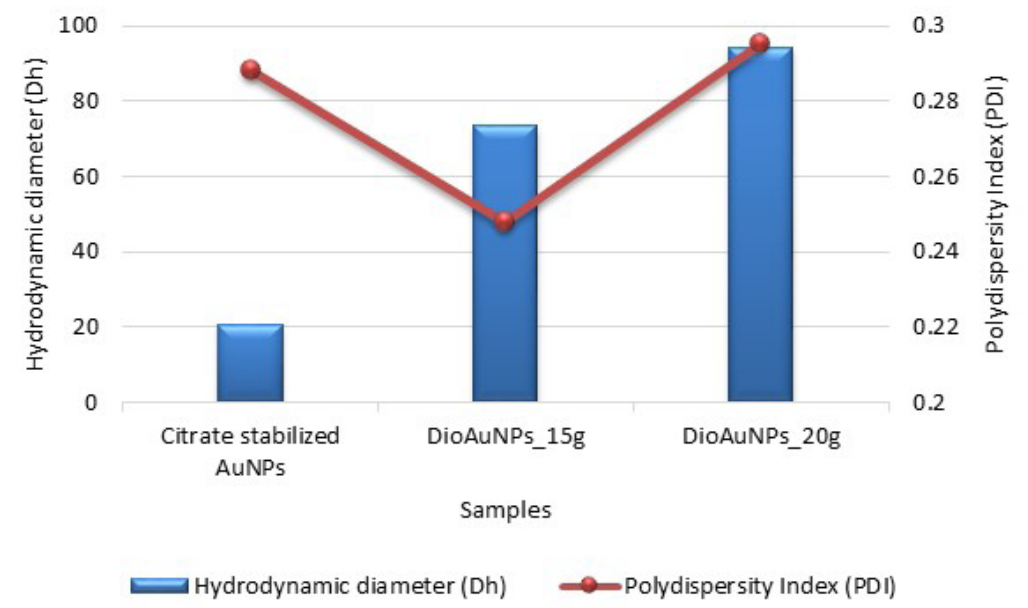

FIGURE 5. Hydrodynamic mean particle diameter (Dh) and polydispersity index (PDI) of citrate-stabilised AuNPs (positive control), DioAuNPs_15g and DioAuNPs_20g

FOURIER-TRANSFORM INFRARED SPECTROSCOPY (FTIR)

In order to identify the possible functional groups of biomolecules in D. claparedii, FTIR was performed.
According to Figure 6, it was showed that D. claparedii contains biomolecules with different functional groups by showing several absorption bands in the IR spectrum.

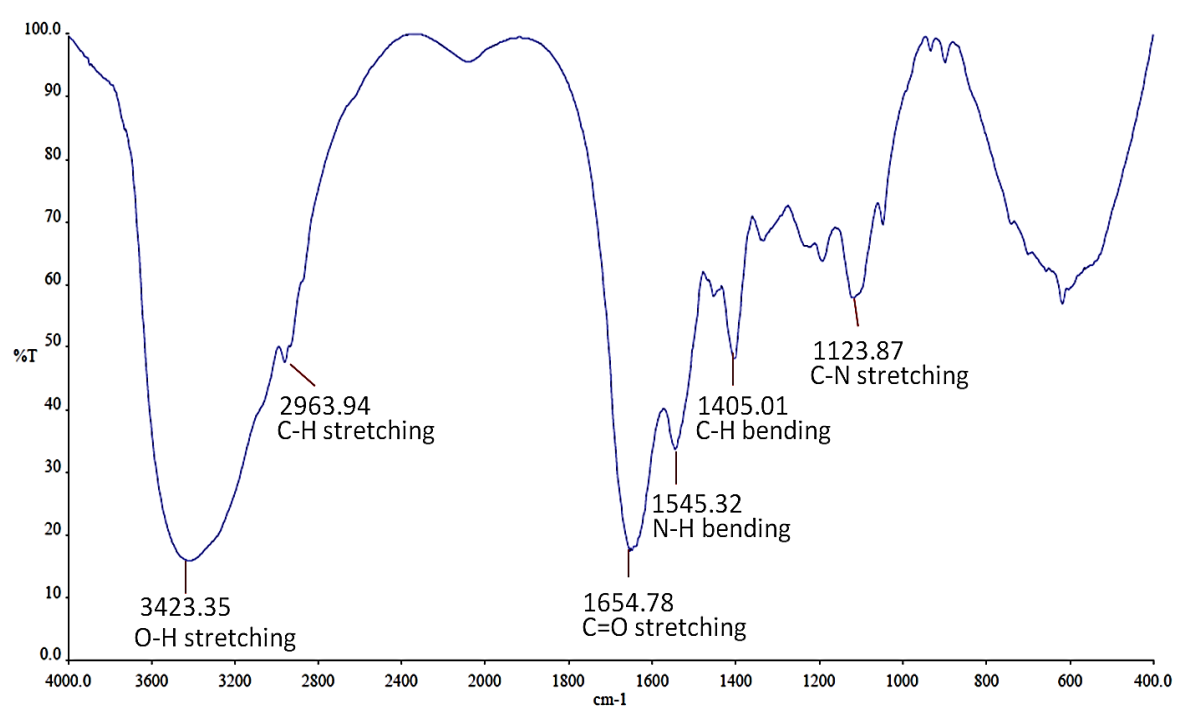

FIGURE 6. FTIR spectrum of $D$. claparedii extract 
The presence of hydroxide group $(v(\mathrm{O}-\mathrm{H})$ stretching $)$ was disclosed as an intense broad band at $3423.35 \mathrm{~cm}^{-1}$. The appearance of this strong band might due to the existence of biocomponents such as carbohydrates and proteins in the polychaetes extract. A weak band at $2963.94 \mathrm{~cm}^{-1}$ is assigned to $v(\mathrm{C}-\mathrm{H})$ stretching bond of hydrocarbon in the sample which probably arises from sugar and protein in the sample.

Furthermore, IR spectrum also showed the presence of carbonyl group, $\mathrm{v}(\mathrm{C}=\mathrm{O})$ stretching of amide by the existence of a strong band at $1654.78 \mathrm{~cm}^{-1}$. The N-H bending bond of primary or secondary amine or amide was showed by appearance of a weak band at 1545.32 $\mathrm{cm}^{-1}$. The bands at 1405.61 and $1123.87 \mathrm{~cm}^{-1}$ could correspond to $v(\mathrm{C}-\mathrm{H})$ bending bond of hydrocarbon and $v(\mathrm{C}-\mathrm{N})$ stretching bond of amine, respectively. However, it was noticed that the peak at around $400 \mathrm{~cm}^{-1}$ to 600 $\mathrm{cm}^{-1}$ which correspond to the peak of metallic particles is absent. This observation confirms the absence of metallic compound in the polychaetes extract, as peak of metalligand stretching bond usually appears at this range of wavenumber (Apte et al. 2013). This finding indicated that D. claparedii extract itself does not contain any metallic compound, including gold, and also proved that AuNPs were biosynthesised by biocomponents of $D$. claparedii extract but not produced naturally and directly from $D$. claparedii itself.

\section{ASSESSMENT OF ANTIBACTERIAL ACTIVITY}

It was observed that the zone of inhibition (ZOI) of tetracycline (antibiotic) for Escherichia coli, Salmonella typhi, Staphylococcus aureus and S. epidermidis are 24 $\pm 1.6,22 \pm 1.2,27 \pm 1.2$, and $24 \pm 0.9 \mathrm{~mm}$, respectively (Table 2). Meanwhile, positive control which is citratestabilised AuNPs gave relatively smaller ZOI than antibiotic which are $14 \pm 1.5$ and $14 \pm 0.6 \mathrm{~mm}$ for $E$. coli and $S$. typhi, while $18 \pm 1.2$ and $18 \pm 0.6 \mathrm{~mm}$ for $S$. aureus and $S$. epidermidis, respectively. D. claparedii extract and double distilled water (positive and negative controls) were found to be inactive in bacteria growth inhibition by showing no inhibition zone for all four bacteria.

TABLE 2. Antibacterial zone of inhibition (ZOI) of the biosynthesised AuNPs and control samples using different types of bacteria

\begin{tabular}{lcccc}
\hline \multicolumn{1}{c}{ Samples } & \multicolumn{3}{c}{ ZOI (mm) } \\
\cline { 2 - 4 } & E. coli & S. typhi & S. aureus & S. epidermidis \\
\hline Antibiotic (Tetracycline) & $24 \pm 1.6$ & $22 \pm 1.2$ & $27 \pm 1.2$ & $24 \pm 0.9$ \\
Citrate-stabilised AuNPs & $14 \pm 1.5$ & $14 \pm 0.6$ & $18 \pm 1.2$ & $18 \pm 0.6$ \\
D. claparedii extract & - & - & - & - \\
Double distilled water & - & - & - & $19 \pm 0.6$ \\
DioAuNPs_15g & $15 \pm 1.2$ & $14 \pm 0.6$ & $21 \pm 0.6$ & $19 \pm 0.3$ \\
DioAuNPs_20g & $17 \pm 0.9$ & $16 \pm 0.6$ & & - \\
\hline
\end{tabular}

a)

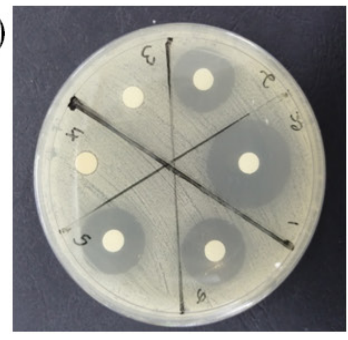

b)

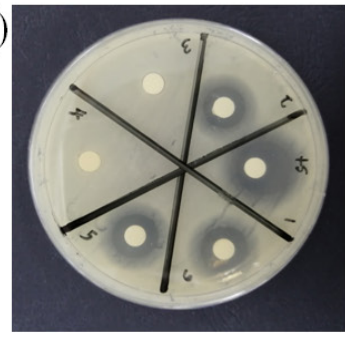

c)

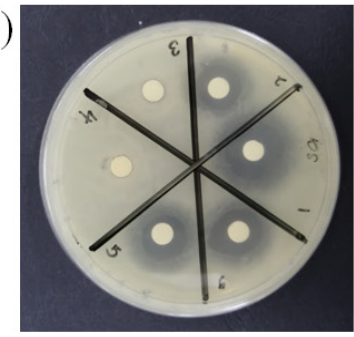

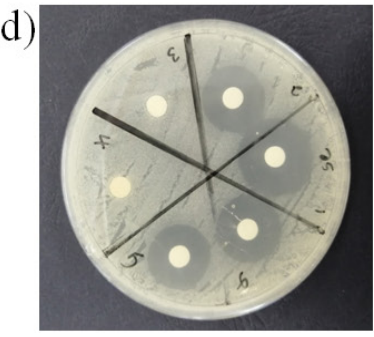

FIGURE 7. Antibacterial assessment conducted with four bacteria: (a) E. coli, (b) S. typhi, (c) S. aureus, and (d) S. epidermidis

Note: (1) Tetracycline, (2) citrate stabilised AuNPs, (3) deionised distilled water (4) polychaete extract, (5) DioAuNPs_15g, and (6) DioAuNPs_20g 
Interestingly, DioAuNPs_15g and DioAuNPs $20 \mathrm{~g}$ exhibited positive results by inhibited the growth of both Gram-positive and Gram-negative bacteria. In general, biosynthesised AuNPs can inhibit the growth of bacteria better than citrate-stabilised AuNPs (positive control) especially for DioAuNPs_20g in both Gram-positive and Gram-negative bacteria (Figure 7). This could probably due to their excellent surface chemistry which makes them easier to adhere to the surface of bacteria and killing it (Zawrah \& Abd El-Moez 2011).

\section{CONCLUSION}

This research was conducted to study the ability of marine invertebrate, $D$. claparedii to biosynthesise AuNPs. It was found that 15 and $20 \mathrm{~g}$ of $D$. claparedii extract have ability to undergo the reduction process of $\mathrm{Au}$ ions to form AuNPs based on the colour changes and the SPR band formation from the UV-Vis analysis. The AuNPs was in spherical shape as visualised by the SEM and TEM images. It also showed that the AuNPs synthesised from the polychaete extract possess good antibacterial properties. Further study will be conducted by optimising several parameters for example $\mathrm{pH}$, temperature, and concentration of reagents in order to determine the most optimum condition to produce biosynthesised AuNPs. Furthermore, isolation of bio-components of $D$. claparedii should be carried out to find out the exact biocomponents involved in biosynthesis process.

\section{ACKNOWLEDGEMENTS}

The authors are thankful to the local indigenous people at Morib, Selangor for their help during the sampling and Universiti Malaysia Terengganu for funding (UMT/RMIC/ TAPE-RG/2018/55146) and great support in this work. We would also like to thank Mrs Suhada Mansor and Mr Mohd Harisfazal Mohamed Basri (Hospital Canselor Tuanku Muhriz UKM, formerly known as Hospital Universiti Kebangsaan Malaysia, Cheras, Kuala Lumpur, Malaysia) for their assistance in TEM, and Kulliyyah of Pharmacy, International Islamic University Malaysia (IIUM), Kuantan, Pahang, Malaysia for the DLS service.

\section{REFERENCES}

Abdel-Raouf, N., Al-Enazi, N.M. \& Ibraheem, I.B.M. 2017. Green biosynthesis of gold nanoparticles using Galaxaura elongata and characterisation of their antibacterial activity. Arabian Journal of Chemistry 10(2): S3029-S3039.

Ahmad, T., Irfan, M., Bustam, M.A. \& Bhattacharjee, S. 2016. Effect of reaction time on green synthesis of gold nanoparticles by using aqueous extract of Elaise guineensis (oil palm leaves). Procedia Engineering 148: 467-472.

Ahmad, T., Wani, I.A., Manzoor, N., Ahmed, J. \& Asiri, A.M. 2013. Biosynthesis, structural characterisation and antimicrobial activity of gold and silver nanoparticles. Colloid and Surface B: Biointerfaces 107: 227-234.

Amendola, V., Pilot, R.M., Frasconi, M., Marago, O.M. \& Lati, M.A. 2017. Surface plasmon resonance in gold nanoparticles: A review. Journal of Physics: Condensed Matter 29(20): 203002.

Apte, M., Girme, G., Nair, R., Bankar, A., Kumar, A.R. \& Zinjarde, S. 2013. Melanin mediated synthesis of gold nanoparticles by Yarrowia lipolytica. Materials Letters 95: 149-152.

Carrillo-Cazares, A., Jiménez-Mancilla, N.P., Luna-Gutiérrez, M.A., Isaac-Olivé, K. \& Camacho-López, M.A. 2017. Study of the optical properties of functionalized gold nanoparticles in different tissues and their correlation with the temperature increase. Journal of Nanomaterials 2017: Article ID. 3628970.

Correard, F., Maximova, K., Estève, M.A., Villard, C., Roy, M., Al-Kattan, M.A., Sentis, M., Gingras, M., Kabashin, A.V. \& Braguer, D. 2014. Gold nanoparticles prepared by laser ablation in aquoues biocompatible solutions: Assessment of safety and biological identity for nanomedicine applications. International Journal of Nanomedicine 9: $5415-5430$

Daraee, H., Eatemadi, A., Abbasi, E., Aval, S.F., Kouhi, M. \& Akbarzadeh, A. 2014. Application of gold nanoparticles in biomedical and drug delivery. Artificial Cells, Nanomedicine and Biotechnology 44(1): 410-422.

Dzimitrowicz, A., Jamróz, P., diCenzo, G.C., Sergiel, I., Kozlecki, T. \& Pohl, P. 2016. Preparation and characterization of gold nanoparticles prepared with aqueous extracts of Lamiaceae plants and the effect of follow-up treatment with atmospheric pressure glow microdischarge. Arabian Journal of Chemistry 12(8): 4118-4130.

Freitas de Freitas, L., Varca, G.H.C., Batista, J.G.S. \& Lugão, A.B. 2018. An overview of the synthesis of gold nanoparticles using radiation technologies. Nanomaterials 8(11): 939-962.

Gatoo, M.A., Naseem, S., Mir Yasir, A., Mahmood Dar, A., Khusro, Q. \& Zubair, S. 2014 Physicochemical properties of nanomaterials: Implication in associated toxic manifestations. Biomed Research International 2014: 498420.

Glasby, C.J., Hutchings, P.A., Fauchald, K., Paxton, H., Rouse, G.W., Russell, C.W. \& Wilson, R.S. 2000. Class polychaeta. In Polychaetes \& Allies: The Southern Synthesis: Vol. Fauna of $A$, edited by Beesley, G.J.B., Ross, C.J. \& Glasby, P.J. Melbourne: CSIRO Publishing. pp. 1-296.

Herizchi, R., Abbasi, E., Milani, M. \& Akbarzadeh, A. 2014. Current methods for synthesis of gold nanoparticles. Artificial Cells, Nanomedicine, and Biotechnology 44(2): 596-602. 
Huang, H.L., Chen, J.K. \& Houng, M.P. 2012. Using soft lithography to fabricate gold nanoparticle patterns for bottom-gate field effect transistors. Thin Solid Films 524: 304-308

Hussain, N.S., Harun, N.A., Radzi, M.N.F.M., Idris, I. \& Ismail, W.I.W. 2018. Biosynthesis of silver nanoparticles from marine polychaete Diopatra claparedii Grube, 1878. Jurnal Teknologi 80(6): 181-187.

Karimi, S., Moshaii, A., Abbasian, S. \& Nikkhah, M. 2018. Surface plasmon resonance in small gold nanoparticles: Introducing a size-dependent plasma frequency for nanoparticles in quantum regime. Plasmonic 14(4): 851-860.

Kim, Y.J., Park, J., Jeong, H.S., Park, M., Baik, S., Lee, D.S., Rho, H., Kim, H., Lee, J.H., Kim, S.M. \& Kim, Y.K. 2019. A seed-mediated growth of gold nanoparticles inside carbon nanotube fibers for fabrication of multifunctional nanohybrid fibers with enhanced mechanical and electrical properties. Nanoscale 11: 5295-5303.

Latha, D., Sampurnam, S., Arulvasu, C., Prabu, P., Govindaraju, K. \& Narayanan, V. 2018. Biosynthesis and characterisation of gold nanoparticle from Justicia adhatoda and its catalytic activity. Materials Today: Proceedings 5(2): 8968-8972.

Lee, S.H., Jung, H.K., Kim, T.C., Kim, C.H., Shin, C.H., Yoon, T.S., Hong, A.R., Jang, H.S., \& Kim, D.H. 2018. Facile method for the synthesis of gold nanoparticles using an ion coater. Applied Surface Science 434: 1001-1006.

Menon, S., Rajeshkumar, S. \& Kumar, V.S. 2017. A review on biogenic synthesis of gold nanoparticles, characterization, and its applications. Resource-Efficient Technologies 3(4): 516-527.

Nadaf, N.Y. \& Kanase, S.S. 2019. Biosynthesis of gold nanoparticles by Bacillus marisflavi and its potential in catalytic dye degradation. Arabian Journal of Chemistry 12(8): 4806-4814

Ogarev, V.A., Rudoi, V.M. \& Dement'eva, O.V. 2018. Gold nanoparticles: Synthesis, optical properties and application. Inorganic Materials: Applied Research 9(1): 134-140.

Onitsuka, S., Hamada, T. \& Okamura, H. 2019. Preparation of antimicrobial gold and silver nanoparticles from tea leaf extracts. Colloid and Surface B: Biointerfaces 173: 242-248.

Paxton, H. 2002. Diopatra Audouin and Milne Edwards (Polychaeta: Onuphidae) from Thailand, Phuket. Thailand: Marine Biological Center Special Publication 24: 101-114.

Pei, A.U.E., Huai, P.C., Masimen, M.A.A., Ismail, W.I.W., Idris, I. \& Harun, N.A. 2020. Biosynthesis of gold nanoparticles (AuNPs) by marine baitworm Marphysa moribidii Idris, Hutchings and Arshad 2014 (annelida: polychaeta) and its antibacterial activity. Advances in Natural Sciences: Nanoscience and Nanotechnology 11(1): 015001.

Ravindran, A., Chandran, P. \& Khan, S.S. 2013. Biofunctionalized silver nanoparticles: Advances and prospects. Colloid and Surface B: Biointerfaces 105: 342352.
Rengan, A.K., Bukhari, A.B., Pradhan, A., Malhotra, R., Banerjee, R., Srivastava, R. \& De, A. 2015. In vivo analysis of biodegradable liposome gold nanoparticles as efficient agents for photothermal therapy cancer. Nano Letters 15(2): 842-848.

Saxena, U. \& Goswami, P. 2012. Electrical and optical properties of gold nanoparticles: Applications in gold nanoparticlescholesterol oxidase integrated systems for cholesterol sensing. Journal of Nanoparticle Research 14: 813.

Singh, P., Kim, Y.J., Zhang, D. \& Yang, D.C. 2016 Biological synthesis of nanoparticles from plants and microorganisms. Trends in Biotechnology 34(7): 588-599.

Singh, R., Sahu, S.K. \& Thangaraj, M. 2014. Biosynthesis of silver nanoparticles by marine invertebrate (polychaete) and assessment of its efficacy against human pathogens. Journal of Nanoparticles 2014(2): 1-7.

Soumya, M., Rajeshkumar, S. \& Venkat, K.S. 2017. A review on biogenic synthesis of gold nanoparticles, characterization and its applications. Resource-Efficient Technologies 3(4): 516-527.

Turkevich, J., Stevenson, P.C. \& Hillier, J. 1953. The formation of colloidal gold. The Journal of Physical Chemistry 57(7): 670-673.

Yang, Y., Li, C., Yin, L., Liu, M., Wang, Z., Shu, Y. \& Li, G. 2014. Enhanced charge transfer by gold nanoparticles at DNA modified electrode and its application to label-free DNA detection. ACS Applied Materials \& Interfaces 6(10): 7579-7584.

Yang, Y., Wang, L., Wan, B., Gu, Y. \& Li, X. 2019. Optically active nanomaterials for bioimaging and targeted therapy. Frontiers in Bioengineering and Biotechnology 7: 320344.

Yeh, Y.C., Creran, B. \& Rotello, V.M. 2012. Gold nanoparticles: Preparation, properties and applications in bionanotechnology. Nanoscale 4(6): 1871-1880.

Yuan, C.G., Huo, C., Yu, S. \& Gui, B. 2017. Biosynthesis of gold nanoparticles using Capsicum annuum var. grossum pulp extract and its catalytic activity. Physica E: LowDimensional Systems and Nanostructures 85: 19-26.

Zawrah, M.F. \& Abd El-Moez, S.I. 2011. Antimicrobial activities of gold nanoparticles against major foodborne pathogens. Life Science Journal 8(4): 37-44.

Zhang, V., Qu, Y., Shen, W., Wang, J., Li, H., Zhang, Z., Li, S. \& Zhou, J. 2016. Biogenic synthesis of gold nanoparticles by yeast Magnusiomyces ingens LH-F1 for catalytic reduction of nitrophenols. Colloid and Surface A: Physicochemical and Engineering Aspects 497: 280-285.

Piong Chong Huai, Noor Aniza Harun*, Angeline Ung Ee Pei, Mohammad Asyraf Adhwa Masimen \& Wan Iryani Wan Ismail Faculty of Science and Marine Environment Universiti Malaysia Terengganu 21030 Kuala Nerus, Terengganu Darul Iman Malaysia 
Noor Aniza Harun*

Advance NanoMaterials (ANOMA) Research Group

Faculty of Science and Marine Environment

Universiti Malaysia Terengganu

21030 Kuala Nerus, Terengganu Darul Iman

Malaysia

Wan Iryani Wan Ismail

Biological Security and Sustainability Research Group

Faculty of Science and Marine Environment

Universiti Malaysia Terengganu

21030 Kuala Nerus, Terengganu Darul Iman

Malaysia
Izwandy Idris

South China Sea Repository \& Reference Centre

Institute of Oceanography \& Environmental

Universiti Malaysia Terengganu

21030 Kuala Nerus, Terengganu Darul Iman

Malaysia

*Corresponding author; email: nooraniza@umt.edu.my

Received: 29 July 2020

Accepted: 5 October 2020 